\title{
Central Bank’s Independence and Stock Prices
}

\author{
Yutaka Kurihara ${ }^{1}$, Koichiro Morikawa ${ }^{2}$, Sadayoshi Takaya ${ }^{3}$ \\ ${ }^{1}$ Faculty of Economics, Aichi University, Nagoya, Japan \\ ${ }^{2}$ Faculty of Economics, Kinki University, Higashiosaka, Japan \\ ${ }^{3}$ Faculty of Commerce, Kansai University, Suita, Japan \\ Email: kurihara@vega.aichi-u.ac.jp
}

Received September 13, 2012; revised October 13, 2012; accepted October 20, 2012

\begin{abstract}
Since the end of 1990s, the independence of central bank independence has been discussed. In the past, central banks tried to improve their independence to combat inflation. This independence has been evaluated relative to adequate economic policy and stable economic growth. This article examines the effect of central bank independence on stock market prices and finds evidence for a positive return in developed countries; moreover, for stock prices, economic independence of the central bank seems to be more important than political independence.
\end{abstract}

Keywords: Central Bank Independence; Monetary Policy; Stock Price

\section{Introduction}

An independent central bank is considered necessary for the conduct of credible monetary policy that is committed to maintain stable inflation [1]. On the other hand, central banks are responsible for the conduct of monetary policy and output [2]. Many studies have noted that higher degrees of central bank independence can keep inflation stable [3,4]. On the other hand, [5] showed that the negative relationship between central bank independence and inflation could not be found by examining the effects on some macroeconomic and institutional variables. As noted in these studies, there is much room for the role of central bank independence to influence for market performance. This article provides evidence that focuses on the question of whether a greater degree of central bank independence results in greater stock returns.

One serious problem exists in this area: very limited data are available regarding reliable central bank independence. Only a few studies have provided this type of data. [4] compared Alestina and Summers's data with those of [6] and found a large increase in central bank independence. To collect the same data and link different time data in one series is difficult. To make a central bank index based on these analyses is still more difficult because the data are sometimes limited. Also, reliable data based full on the past is almost impossible. Some possibility exists that different situations may have impacted the determination of central bank independence. On the other hand, a few studies have been evaluated highly and cited often. Moreover, the use of data for em- pirical analysis sometimes causes problems as these established papers provide fixed data for some sample period.

This article contributes to the limited literature that goes beyond the effects of central bank independence on inflation ([7-9]). [10] focused on the effects of central bank independence on exchange rates. [11] found that central bank independence favorably affected employment rates. However, as there has been little reliable and broadly accepted data for central bank independence, especially for the recent period, the need to analyze the relationship between central bank independence and economic variables has increased. This article responds to this need.

[11] stated that an independent central bank fosters stock market returns by constraining inflation. [12,13] investigated the effect of central bank independence on stock market in emerging economies. The former found that high government turnover has a negative effect on stock market returns. The latter indexed central bank independence index into two categories (i.e., economic and political) and found evidence for a positive return; however, the economic independence of the central bank seems to be more important than political independence in developing and emerging countries.

However, few studies have considered central bank independence relative to many countries, the recent period, and the effects of central bank independence on macroeconomic variables. Few studies have assessed the relationship between stock prices and macroeconomic variables.

This article examines empirically the effects of central 
bank independence on stock prices as well as the effects of some macroeconomic variables on stock prices. The central bank independence index is drawn from two famous ones [1,13], which have been cited frequently. Two groups of countries area used for this analysis: developed economies and developing/emerging economies. A comparison of these categories seems very important for the conduct of monetary policy and for stable growth. Although the ideal would be to use a reliable central bank index, it is difficult to collect this type of data. Two reliable data $[9,13]$ are employed in this article. However, political and economic elements of the two indices are distinguished to analyze the effects of the central bank independence and some economic variables on stock prices.

\section{Theoretical Analysis}

This article empirically examines the effect of central bank independence and economic variables on stock market prices. The equation for the empirical analysis is as follows:

$$
\text { STOCKit }=\text { Const }+\alpha \text { CBIit }+\beta \text { Xit }+\varepsilon i t
$$

STOCK means year-to-year percentage change of stock prices. CBI denotes central bank independence index. $\mathrm{X}$ means four macroeconomic variables related to stock prices (explained in 3-1 in detail). i denotes country and $t$ means time. This equation is orthodox and not new as based on [1]. Both the effect of CBI effect on stock prices and some related macroeconomic variables with stock prices and goals of central banks are added as explanation variables for empirical estimation. This equation is orthodox and not new as based on [1].

The effect of CBI on stock prices is the main focus of this article; it cannot be omitted. Second, almost all of the central banks conduct their policies to attain stable inflation rates. Inflation rate should be examined. Third, interest rate is the most important factor for determination of stock prices. It is added as an explanation variable. Fourth, as most central banks are interested in economic growth, GDP growth is used as an explanation variable. Finally, export growth is added as an explanation variable as per [1], because not only the cases of developed but also those of emerging and developed countries are employed for estimation. Some developing and emerging economics depend on exports for economic growth, namely, in stock prices.

The main interest is in the effects of CBI on stock prices. The CBI indices used here are the Cukierman and Arnone index of the subindices for political independence and economic independence, together and in total. All measures of CBI are measured for the period for which the returns are calculated. Changes do not always represent permanent shifts in the level of the CBI proxy.

\section{Empirical Method and Results}

\subsection{Empirical Method}

The data are yearly. For central bank independence, the data derived from $[9,13]$ are both used. The two papers provided data regarding central bank independence; all data are fixed. The sample periods are from 1989 to 1992 for the index of [13] and from 2005 to 2007 for the index of [9]. These indices are based on information about central bank independence across 10 dimensions. $[9,13]$ are combined with different weights in an economic and political independence index. Both economic and political factors are taken into account.

[14] found that the differences in behaviors among central banks are consistent with the economic measure of independence, which measures how easy it is for the government to finance its deficits by direct access to credit from the central bank. For example, one of the economic differences is whether or not the central bank is obliged to finance government debt, and one of the political differences is the relationship between the central bank and the government in determining monetary policy. Both economic and political elements should be considered in determining the central bank index.

This article divides the countries into two groups: 1) developed countries and 2) developing or emerging countries. For developed countries, the countries estimated are Australia, Austria, Belgium, Korea, Netherlands, New Zealand, Norway, Portugal, Singapore, Spain, Sweden, Switzerland, the United Kingdom, and the United States. Developing and emerging economies include Barbados, Columbia, Israel, Malta, Peru, Philippines, South Africa, Turkey, and Venezuela. Only the countries selected were examined in this analysis due to the data available.

The stock market prices are percentage year-to-year change and are used for dependent variables. Explanatory variables include the index of central bank independence, inflation, GDP growth, export growth, and interest rate. All of the data except the index of central bank independence are percentage year-to-year change and are from International Financial Statistics (International Monetary Fund). Three indices are used for central bank independence: total, economic, and political.

It is necessary to check unit root tests for estimation. This paper uses two typical methods: augmented DickeyFuller (ADF) and Phillips-Perron (PP). ADF is most used for empirical estimation; however, if the series is correlated at higher order lags, the assumption of white noise disturbances is violated. The PP test proposes a method by which to control for higher order serial correlation in a series than is accepted in the equation. The test makes a 
nonparametric correction to the t-test statistic. This is robust with respect to unspecified autocorrelation and heteroscedasticity in the disturbance process of the test equation.

The results of two methods explained are in Tables 1(a)-(c). In a few cases, the results are mixed and are not perfectly conclusive. However, almost all of the results are not problematic for empirical estimations.

\subsection{Empirical Results}

The results of the equation (1) are shown in Tables 2(a)(c). The regression method is OLS (ordinary least squared).

The results are clear. Central bank independence has positive impact on stock prices in general. However, the results show that it is necessary to distinguish developed countries from other countries. The results show positive evidence that central bank independence increases stock

Table 1. (a) Unit root test: Total countries; (b) Unit root test: Developed countries; (c) Unit root test: Developing and emerging countries.

(a)

\begin{tabular}{lll}
\hline & ADF & PP \\
\hline Stock return & $-3.20^{* * *}$ & $-52.80^{* * *}$ \\
Inflation & 0.23 & $-62.89^{* * *}$ \\
GDP growth & $-3.36^{* * *}$ & $-20.89^{* * *}$ \\
Export growth & $-3.03^{* *}$ & $-48.12^{* * *}$ \\
Interest rate & -0.37 & $-63.14^{* * *}$ \\
\hline
\end{tabular}

\begin{tabular}{lll}
\multicolumn{2}{c}{ (b) } \\
\hline ADF & PP \\
\hline Stock return & $-3.24^{* * *}$ & $-47.02^{* * *}$ \\
Inflation & $-2.43^{* * *}$ & $-32.61^{* * *}$ \\
GDP growth & $-3.93^{* * *}$ & $-40.28^{* * *}$ \\
Export growth & $-1.63^{*}$ & $-59.36^{* * *}$ \\
Interest rate & $-2.60^{* *}$ & $-32.47^{* * *}$ \\
\hline
\end{tabular}

\begin{tabular}{lll} 
& \multicolumn{2}{c}{ (c) } \\
\hline & ADF & PP \\
\hline Stock return & $-2.46^{* *}$ & $-17.88^{* * *}$ \\
Inflation & $-2.37^{* *}$ & $-16.16^{* * *}$ \\
GDP growth & $-2.04^{* *}$ & $-18.22^{* * *}$ \\
Export growth & $-3.88^{* * *}$ & $-9.69^{* * *}$ \\
Interest rate & $-2.44^{* *}$ & $-10.37^{* * *}$ \\
\hline
\end{tabular}

Note. ${ }^{* * *}$ means significant at $1 \%,{ }^{* *}$ means at $5 \%$, and ${ }^{*}$ means at $10 \%$ level.
Table 2. (a) Effects of central bank independence on stock returns: Total countries; (b) Effects of central bank independence on stock returns: Developed countries; (c) Effects of central bank independence on stock returns: Developing and emerging countries.

\begin{tabular}{|c|c|c|c|}
\hline \multirow{3}{*}{ Variable } & \multirow{2}{*}{\multicolumn{3}{|c|}{ Central bank independence }} \\
\hline & & & \\
\hline & Political & Economic & Total \\
\hline C & $\begin{array}{l}-20.75 \\
(-1.61)\end{array}$ & $\begin{array}{c}-41.89^{* *} \\
(-2.71)\end{array}$ & $\begin{array}{c}-44.48^{* *} \\
(-3.00)\end{array}$ \\
\hline Stock return $(-1)$ & $\begin{array}{c}0.47 \\
(2.79)\end{array}$ & $\begin{array}{l}0.41^{* *} \\
(2.53)\end{array}$ & $\begin{array}{l}0.47^{* *} \\
(2.95)\end{array}$ \\
\hline Central bank independence & $\begin{array}{l}42.06^{* *} \\
(2.75)\end{array}$ & $\begin{array}{c}54.72^{* * * *} \\
(3.58)\end{array}$ & $\begin{array}{c}70.91^{* * * *} \\
(3.99)\end{array}$ \\
\hline Inflation rate & $\begin{array}{l}2.73^{* * *} \\
(19.36)\end{array}$ & $\begin{array}{l}0.14^{* * * *} \\
(19.87)\end{array}$ & $\begin{array}{l}2.67^{* * *} \\
(19.70)\end{array}$ \\
\hline GDP growth & $\begin{array}{l}-0.78 \\
(-0.51)\end{array}$ & $\begin{array}{l}-0.55 \\
(-0.37)\end{array}$ & $\begin{array}{l}-0.07 \\
(-0.05)\end{array}$ \\
\hline Export growth & $\begin{array}{c}0.15 \\
(0.28)\end{array}$ & $\begin{array}{c}0.50 \\
(1.00)\end{array}$ & $\begin{array}{c}0.18 \\
(0.38)\end{array}$ \\
\hline Interest rate & $\begin{array}{c}-0.14 \\
(-0.26)\end{array}$ & $\begin{array}{c}0.06 \\
(0.16)\end{array}$ & $\begin{array}{c}0.15 \\
(0.29)\end{array}$ \\
\hline \multirow{4}{*}{$\begin{array}{l}\text { Adj. } \mathrm{R}^{2} \\
\text { F-statistic } \\
\text { Durbin Watson }\end{array}$} & 0.99 & 0.99 & 0.99 \\
\hline & 15170.83 & 16409.09 & 17142.20 \\
\hline & 2.40 & 2.32 & 2.28 \\
\hline & (b) & & \\
\hline \multirow{2}{*}{ Variable } & \multicolumn{3}{|c|}{ Central bank independence } \\
\hline & Political & Economic & Total \\
\hline $\mathrm{C}$ & $\begin{array}{c}9.61 \\
(1.19)\end{array}$ & $\begin{array}{l}-9.18 \\
(-0.79)\end{array}$ & $\begin{array}{l}-1.79 \\
(-0.15)\end{array}$ \\
\hline Stock return $(-1)$ & $\begin{array}{l}0.32^{* *} \\
(2.88)\end{array}$ & $\begin{array}{l}0.37^{* * * *} \\
(3.47)\end{array}$ & $\begin{array}{l}0.36^{* *} \\
(3.21)\end{array}$ \\
\hline Central bank independence & $\begin{array}{c}0.62 \\
(0.08)\end{array}$ & $\begin{array}{l}18.22^{* * *} \\
(1.96)\end{array}$ & $\begin{array}{l}14.47 \\
(1.20)\end{array}$ \\
\hline Inflation rate & $\begin{array}{l}-1.85 \\
(-1.34)\end{array}$ & $\begin{array}{l}-1.23 \\
(-0.93)\end{array}$ & $\begin{array}{l}-1.30 \\
(-0.93)\end{array}$ \\
\hline GDP growth & $\begin{array}{l}-2.34^{* *} \\
(-2.21)\end{array}$ & $\begin{array}{l}-1.70^{*} \\
(-1.60)\end{array}$ & $\begin{array}{l}-1.84^{*} \\
(-1.70)\end{array}$ \\
\hline Export growth & $\begin{array}{l}1.42^{* * * *} \\
(4.10)\end{array}$ & $\begin{array}{l}1.53^{* * * *} \\
(4.84)\end{array}$ & $\begin{array}{l}1.37^{* * * *} \\
(4.21)\end{array}$ \\
\hline Interest rate & $\begin{array}{l}-0.88 \\
(-1.19)\end{array}$ & $\begin{array}{l}-0.70 \\
(-0.99)\end{array}$ & $\begin{array}{l}-0.87 \\
(-1.20)\end{array}$ \\
\hline \multirow{3}{*}{$\begin{array}{l}\text { Adj. }{ }^{2} \\
\text { F-statistic } \\
\text { Durbin Watson }\end{array}$} & 0.93 & 0.98 & 0.95 \\
\hline & 9.20 & 10.79 & 9.79 \\
\hline & 1.62 & 1.64 & 1.64 \\
\hline & (c) & & \\
\hline \multirow{2}{*}{ Variable } & \multicolumn{3}{|c|}{ Central bank independence } \\
\hline & Political & Economic & Total \\
\hline C & $\begin{array}{l}-24.53 \\
(-0.81)\end{array}$ & $\begin{array}{l}-31.51 \\
(-0.89)\end{array}$ & $\begin{array}{l}-36.48 \\
(-1.08)\end{array}$ \\
\hline Stock return $(-1)$ & $\begin{array}{c}0.53 \\
(1.47)\end{array}$ & $\begin{array}{c}0.44 \\
(1.33)\end{array}$ & $\begin{array}{c}0.43 \\
(1.16)\end{array}$ \\
\hline Central bank independence & $\begin{array}{l}74.50 \\
(1.15)\end{array}$ & $\begin{array}{l}48.03 \\
(1.00)\end{array}$ & $\begin{array}{l}80.86 \\
(1.31)\end{array}$ \\
\hline Inflation rate & $\begin{array}{l}2.58^{* * * *} \\
(8.58)\end{array}$ & $\begin{array}{l}2.55^{* * * *} \\
(8.51)\end{array}$ & $\begin{array}{l}2.59^{* * * *} \\
(8.75)\end{array}$ \\
\hline GDP growth & $\begin{array}{c}2.13 \\
(0.75)\end{array}$ & $\begin{array}{c}2.04 \\
(0.66)\end{array}$ & $\begin{array}{c}2.12 \\
(0.70)\end{array}$ \\
\hline Export growth & $\begin{array}{l}-1.13 \\
(-1.02)\end{array}$ & $\begin{array}{l}-0.93 \\
(-0.84)\end{array}$ & $\begin{array}{l}-1.05 \\
(-0.96)\end{array}$ \\
\hline Interest rate & $\begin{array}{c}0.49 \\
(0.43)\end{array}$ & $\begin{array}{c}0.71 \\
(0.64)\end{array}$ & $\begin{array}{c}0.57 \\
(0.53)\end{array}$ \\
\hline Adj. $R^{2}$ & 0.99 & 0.99 & 0.99 \\
\hline F-statistic ${ }^{*}$ total & 5970.871 & 5846.20 & 6011.03 \\
\hline Durbin Watson ${ }^{*}$ total & 2.34 & 2.34 & 2.38 \\
\hline
\end{tabular}


prices for developed economies, however, the relationship cannot be found for developing and emerging economies. Also, there is large difference between the usage of the political element and the economic element.

All of the coefficients of central bank independence on stock prices are positive and significant for developed economies. However, only the economic indices are significant. The effects of inflation on stock prices reflect the results that adj. $\mathbf{R}^{2} \mathrm{~s}$ are small in Table 2(b). For the case of developing and emerging economies, the coefficients are positive as expected; however, not all of them are significant.

The results show strongly that it would be dangerous to state that improvements in central bank independence cause stock prices to rise. Considering economic conditions/stages and elements of central bank independence would be necessary for policymakers to attain economic development. Also, economic elements of central bank independence should be carefully examined. Systematic and reasonable policy for economic development to fit each economy would be necessary and important.

It is interesting to note that exporting growth promotes stock price rising in developed countries (but not in developing and emerging economies). GDP growth is not necessarily linked to increases in stock prices. In developing and emerging economies, inflation promotes increased stock prices. Deflation and domestic demand have been serious in developed economies, which may have some effect on these results.

Also, it is interesting to note that central bank independence increases inflation for developing and emerging economies. The reason is difficult to understand. There is some possibility that central banks which have high independence do not strong emphasis on inflation. Also, inflation may be caused by other factors such as asset prices.

The Granger causality test was performed to check the hypothesis (see Tables 3(a)-(c)). The Granger causality test is a statistical hypothesis test that determines whether a time series is useful for forecasting. A time series $\mathrm{X}$ is said to Granger cause $Y$ if it can be shown in a serious of $\mathrm{F}$ tests on lagged values of $\mathrm{X}$ and that those $\mathrm{X}$ values provide significant data about future values of $Y$.

The results show positive evidence that central bank independence increases stock prices.

\section{Conclusions}

This article examined the effects of central bank independence on stock prices. Almost all of the results are clear. The results show evidence of positive stock returns as central bank independence improves; most notably, economic independence of the central bank is more important than political independence. However, these results could not be found for developing and emerging
Table 3. (a) Granger causality test: Total countries. (b) Granger causality test: Developed countries; (c) Granger causality test: Developing and emerging countries.

(a)

\begin{tabular}{|c|c|c|}
\hline & F-statistic & Prob. \\
\hline $\begin{array}{l}\text { Central bank independence does not } \\
\text { Granger cause stock return }\end{array}$ & 0.08 & 0.77 \\
\hline $\begin{array}{l}\text { Stock does not Granger cause } \\
\text { central bank independence }\end{array}$ & 0.34 & 0.56 \\
\hline
\end{tabular}

\begin{tabular}{|c|c|c|}
\hline \multicolumn{3}{|l|}{ (b) } \\
\hline & F-statistic & Prob. \\
\hline $\begin{array}{l}\text { Central bank independence does not } \\
\text { Granger cause stock return }\end{array}$ & 5.86 & 0.006 \\
\hline $\begin{array}{l}\text { Stock does not Granger cause } \\
\text { central bank independence }\end{array}$ & 1.95 & 0.16 \\
\hline \multicolumn{3}{|l|}{ (c) } \\
\hline & F-statistic & Prob. \\
\hline $\begin{array}{l}\text { Central bank independence does not } \\
\text { Granger cause stock return }\end{array}$ & 1.72 & 0.20 \\
\hline $\begin{array}{l}\text { Stock does not Granger cause } \\
\text { central bank independence }\end{array}$ & 4.50 & 0.08 \\
\hline
\end{tabular}

economies. The empirical results show strongly the effects of the independence of central banks along with the differences among countries, regions, and so on.

The political aspect of central bank independence does not appear to exert a strong influence on stock returns. Other aspects should be considered carefully and taken into account. [15] showed that leftist governments had somewhat lower interest rates than right-wing governments when central bank independence is low. [16] also showed that high central bank independence may require a high level of conservatism. There is much room for discussion.

\section{Acknowledgements}

We appreciate a referee's comments and suggestions.

\section{REFERENCES}

[1] T. Förch and U. Sunde, "Central Bank Independence and Stock Market Returns in Emerging Economies," Economics Letters, Vol. 115, No. 1, 2012, pp. 77-80. doi:10.1016/j.econlet.2011.11.030

[2] Y. Kurihara, "Inflation Targeting and the Role of the Exchange Rate: The Case of the Czech Republic,” International Business Research, Vol. 5, No. 3, 2012, pp. 33-39. doi:10.5539/ibr.v5n3p33

[3] J. Forder, "Why Is Central Bank Independence So Widely Approved?” Journal of Economic Issues, Vol. 39, No. 4, 2005, pp. 843-865.

[4] C. T. Carlstorm and T. S. Fuerst, "Central Bank Inde- 
pendence and Inflation: A Note,” Economic Inquiry, Vol. 47, No. 1, 2009, pp. 182-186.

[5] G. Petrevski, J. Bogoev and B. S. Sergi, "The Link between Central Bank Independence and Inflation in Central and Eastern Europe: Are the Results Sensitive to Endogeneity Issue Omitted Dynamics and Subjectivity Bias?” Journal of Post Keynesian Economics, Vol. 34, No. 4, 2012, pp. 611-621. doi:10.2753/PKE0160-3477340403

[6] C. Hefeker and B. Zimmer, "The Optimal Choice of Central Bank Independence and Conservatism under Uncertainty," Journal of Macroeconomics, Vol. 33, No. 4, 2011, pp. 595-615. doi:10.1016/j.jmacro.2011.09.005

[7] A. Alesina and A. Summers, "Central Bank Independence and Macroeconomic Performance: Some Comparative Evidence,” Journal of Money, Credit and Banking, Vol. 25, No. 2, 1993, pp. 151-162. doi:10.2307/2077833

[8] B. Neyapti, “Central Bank Independence and Economic Performance in Eastern Europe,” Economic Systems, Vol. 25, No. 4, 2001, pp. 381-399. doi:10.1016/S0939-3625(01)00033-4

[9] M. Arnone, B. J. Laurens and J.-F. Segelotto, "Central Bank Autonomy: Lessons from Global Trends," IMF Working Paper, No. 88, 2009. doi:10.1057/imfsp.2008.25

[10] K. N. Kuttner and A. S. Posen, "Do Markets Care Who Chairs the Central Bank," Journal of Money, Credit, and Banking, Vol. 42, No. 2, 2010, pp. 347-371.
[11] M. Fry, D. Julius, L. Mahadeva, S. Roger and G. Ssterne, "Key Issues in the Choice of Monetary Policy Framework,” In: J. Mahadeva and S. Sterne, Eds., Monetary Policy Frameworks in a Global Context, Routledge, London, 2000, pp. 50-66.

[12] C. Moser and A. Dreher, "Do Markets Care about Central Bank Governor Changes? Evidence from Emerging Markets," Journal of Money, Credit and Banking, Vol. 42, No. 5, 2010, pp. 1589-1612. doi:10.1111/j.1538-4616.2010.00355.x

[13] A. Cukierman, A, Webb and S. Neyapti, "Measuring the Independence of Central Banks and Its Effects on Policy Outcomes," World Bank Economic Review, Vol. 6, No. 3, 1992, pp. 353-398. doi:10.1093/wber/6.3.353

[14] C. J. Hueng, "Central Bank Behavior and Statutory Independence,” Atlantic Economic Journal, Vol. 40, No. 2, 2012, pp. 111-126. doi:10.1007/s11293-012-9310-x

[15] A. Belke and N. Potrafke, "Does Government Ideology Matter in Monetary Policy? A Panel Data Analysis for OECD Countries,” Journal of International Money and Finance, Vol. 31, No. 5, 2012, pp. 1126-1150.

[16] H. Feldmann, "Central Bank Independence, Wage Bargaining, and Labor market Performance: New Evidence," Southern Economic Journal, Vol. 77, No. 3, 2011, pp. 692-725. doi:10.4284/sej.2011.77.3.692 